\title{
PENGARUH PEMBERIAN TEKNIK MARMET TERHADAP PRODUKSI ASI PADA IBU POST PARTUM DI BPM WILAYAH KERJA PUSKESMAS SUKORAME KOTA KEDIRI
}

\author{
Astri Dwi Ningrum, Ira Titisari, Finta Isti Kundarti, Arika Indah Setyarini \\ *= Politeknik Kesehatan Kemenkes Malang, Jurusan Kebidanan, Kampus Kediri
}

\begin{abstract}
The decrease of breast milk production of postpartum mother in the early breast feeding process that become a problem for mother to provide breast milk early on her baby. Based on a preliminary study of the lowest exclusive breastfeeding rate coverage in the Kediri city is at Sukorame Public Health Center. This is because many postpartum mothers who felt less that give their milk formula or food other than breast milk in early lactation. The breast milk production could be stimulated by the use of intervention marmet technique. The purpose of this study was to investigate the influence of giving marmet technique to the breast milk production of the postpartum mother. This study is a quasi-experimental research design with post-test only control group design. The population in this study were all post partum mothers who met the inclusion criteria for the study in BPM working area of Sukorame Public Health Center Kediri City. The sampling technique is consecutive sampling with a sample of 26 respondents. Data collection was done by dividing into 2 groups: the experimental group and the control group and to assess the breast milk production using the observation sheet of breast milk production. Data analysis technique used is the Fisher Exact Test Test. The results obtained $\mathrm{p}$ value count $(0.0074)<\propto=(0.05)$ then $\mathrm{H}_{0}$ is rejected, meaning that there is the effect of giving marmet technique to the breast milk production. The conclusion of this study was the Marmet technique affects breast milk production of post partum mother. Giving Marmet technique can be applied to help the adequacy of breast milk production. Suggestions researchers is that all medical person can continue to support the improvement of service quality by taking into account maternal postpartum milk production that can impact the breastfeeding process.
\end{abstract}

Keywords: marmet technique, breast milk production, post partum

\section{PENDAHULUAN}

Laktasi adalah keseluruhan proses menyusui mulai dari Air Susu Ibu (ASI) di produksi sampai proses bayi menghisap dan menelan ASI. Sementara itu, yang dimaksud manajemen laktasi ialah suatu upaya yang dilakukan oleh ibu, ayah, dan keluarga untuk menunjang keberhasilan menyusui. Ruang lingkup pelaksanaan manajemen laktasi dimulai pada masa kehamilan, setelah persalinan, dan masa menyusui bayi. Aktivitas menyusui bayi dapat merangsang rahim untuk mengecil. Pemeriksaan dokter pada akhir minggu ke-6, biasanya rahim berukuran lebih kecil dan lebih kencang dari pada ibu yang tidak menyusui. Masa laktasi mempunyai tujuan meningkatkan pemberian ASI eksklusif dan meneruskan pemberian ASI sampai anak umur 2 tahun secara baik dan benar serta anak mendapatkan kekebalan tubuh secara alami (Prasetyono, 2009).

ASI adalah makanan bayi ciptaan Tuhan sehingga tidak dapat digantikan dengan makanan dan minuman yang lain. ASI merupakan makanan bayi yang terbaik dan setiap bayi berhak mendapatkan ASI, dan untuk mempromosikan pemberian ASI, maka Kementerian Kesehatan telah menerbitkan 
surat keputusan Menteri Kesehatan nomor: 450/Menkes/SK/IV/2004 tentang Pemberian ASI secara eksklusif pada bayi di Indonesia. Pada tahun 2012 telah terbit Peraturan Pemerintah (PP) nomor 33 tentang Pemberian ASI Eksklusif dan telah diikuti dengan diterbitkannya 2 (dua) Peraturan Menteri Kesehatan yaitu : Permenkes Nomor 15 Tahun 2013 tentang Tata Cara Penyediaan Fasilitas Khusus Menyusui Dan/Atau Memerah Air Susu Ibu dan Permenkes Nomor 39 Tahun 2013 tentang Susu Formula Bayi dan Produk Bayi Lainnya (Depkes gizi, 2013).

Anak-anak yang mendapat ASI eksklusif 14 kali lebih mungkin untuk bertahan hidup dalam enam bulan pertama kehidupan dibandingkan anak yang tidak disusui. Mulai menyusui pada hari pertama setelah lahir dapat mengurangi risiko kematian bayi baru lahir hingga 45 persen. Selain manfaat bagi bayi, ibu yang memberikan ASI eksklusif juga berkecenderungan lebih kecil untuk menjadi hamil lagi dalam enam bulan pertama setelah melahirkan dan lebih cepat pulih dari persalinan. Meskipun manfaat-manfaat dari menyusui ini telah didokumentasikan di seluruh dunia, hanya 39 persen anak-anak di bawah enam bulan mendapatkan ASI eksklusif pada tahun 2012. Angka global ini hanya meningkat dengan sangat perlahan selama beberapa dekade terakhir, sebagian karena rendahnya tingkat menyusui di beberapa negara-negara besar, dan kurangnya dukungan untuk ibu menyusui dari lingkungan sekitar (Unicef, 2013).

Data Riset Kesehatan Dasar (Riskedas) 2013 menunjukkan cakupan ASI di Indonesia hanya 42 persen. Angka ini jelas berada di bawah target WHO yang mewajibkan cakupan ASI hingga 50 persen. Angka kelahiran di Indonesia mencapai 4,7 juta per tahun, maka bayi yang memperoleh ASI selama enam bulan hingga dua tahun, tidak mencapai dua juta jiwa. Angka ini menandakan hanya sedikit anak Indonesia yang memperoleh kecukupan nutrisi dari ASI. Riset Eropa membuktikan pemberian ASI mendukung anak meraih pendidikan lebih tinggi. Hasil senada diperoleh riset yang dilakukan di Denmark pada 3.203 anak. Anak yang menyusu ASI kurang dari satu bulan memiliki tingkat IQ lebih rendah dibanding yang memperoleh ASI hingga 7-9 bulan. ASI juga meningkatkan daya tahan tubuh anak. Berdasarkan riset yang dimuat dalam buletin Lancet pada tahun 2013 diungkapkan, pemberian ASI bisa menekan kematian balita hingga 13 persen (Widiani, 2013).

Penelitian yang dilakukan oleh Siregar (2004) menunjukkan bahwa pemberian ASI eksklusif dipengaruhi oleh berbagai faktor antara lain ASI tidak segera keluar setelah melahirkan / produksi ASI kurang, kesulitan bayi dalam menghisap, keadaan puting susu ibu yang tidak menunjang, ibu bekerja, dan pengaruh/promosi pengganti ASI. Colin dan Scott (2002) dalam penelitiannya yang dilakukan di Australia menjelaskan bahwa 29 persen ibu post partum berhenti menyusui karena produksi ASI berkurang. Kenyataan di lapangan menunjukkan produksi dan ejeksi ASI yang sedikit pada hari-hari pertama setelah melahirkan menjadi kendala dalam pemberian ASI secara dini. Menurut Cox (2006) disebutkan bahwa ibu yang tidak menyusui bayinya pada hari-hari pertama menyusui disebabkan oleh kecemasan dan ketakutan ibu akan kurangnya produksi ASI serta kurangnya pengetahuan ibu tentang proses menyusui (Mardiyaningsih, 2010).

Teknik marmet mengeluarkan ASI secara manual dan membantu refleks pengeluaran susu (Milk Ejection Reflex) telah bekerja bagi ribuan ibu dengan cara yang tidak dimiliki sebelumnya. Bahkan ibu menyusui berpengalaman yang telah mampu mengeluarkan ASI diungkapkan akan menghasilkan lebih banyak susu dengan metode ini. Ibu yang sebelumnya telah mampu mengeluarkannya hanya sedikit, atau tidak sama sekali, mendapatkan hasil yang sangat baik 
dengan teknik ini. Teknik Marmet mengembangkan metode pijat dan stimulasi untuk membantu kunci reflek keluarnya ASI. Keberhasilan dari teknik ini adalah kombinasi dari metode pijat dan pengeluaran ASI. Teknik ini efektif dan tidak menimbulkan masalah (Hormann, 2006). Teknik marmet ini merupakan salah satu cara yang aman yang dapat dilakukan untuk merangsang payudara untuk memproduksi lebih banyak ASI (Nurdiansyah, 2011).

Berdasarkan studi pendahuluan, peneliti memperoleh data dari Dinkes Kota Kediri berupa data cakupan ASI eksklusif Kota Kediri tahun 2011 dan tahun 2012. Data tersebut menunjukkan bahwa terjadi penurunan pencapaian ASI eksklusif di Kota Kediri. Hal ini juga terjadi pada pencapaian ASI eksklusif di Puskesmas Sukorame Kota Kediri, dimana pada tahun 2011 hanya tercapai 42,2 \% dan pada tahun 2012 turun menjadi $29,44 \%$, dimana posisi tersebut merupakan posisi terendah cakupan ASI eksklusif di wilayah Kota Kediri. Hasil cakupan tersebut tentunya masih jauh dari target yang ditetapkan oleh Dinas Kesehatan Kota Kediri yaitu sebesar 95\%. Menurut keterangan dari Puskesmas Sukorame, hal ini disebabkan karena banyaknya ibu post partum yang merasa produksi ASInya kurang sehingga memberikan susu formula atau makanan selain ASI. Hasil studi pendahuluan yang dilakukan pada 2 BPM yang aktif melayani persalinan yaitu pada BPM Endang Sumaningdyah diketahui bahwa dari 9 ibu post partum, 6 ibu sudah memberikan susu formula karena produksi ASI kurang dan 3 ibu masih memberikan ASI secara eksklusif. Sedangkan studi pendahuluan yang dilakukan di BPM Kurniawati diketahui bahwa dari 5 ibu post partum, 3 ibu sudah memberikan susu formula dan 2 ibu masih memberikan ASI secara eksklusif.

Dengan melihat latar belakang di atas, maka dirasa perlu untuk memberikan intervensi berupa pemberian teknik marmet terhadap produksi ASI, sehingga peneliti tertarik untuk melakukan penelitian tentang "Pengaruh pemberian teknik marmet terhadap produksi ASI pada ibu post partum di BPM Wilayah Kerja Puskesmas Sukorame Kota Kediri."

\section{METODE PENELITIAN}

Penelitian ini menggunakan jenis penelitian Quasy-Eksperiment. Rancangan penelitian yang digunakan Post Only Design with control group, yaitu suatu pengukuran hanya dilakukan pada saat terakhir penelitian dengan cara melibatkan kelompok kontrol di samping kelompok eksperimen (Notoatmodjo, 2010). Populasi dalam penelitian ini adalah semua ibu post partum yang memenuhi kriteria inklusi selama penelitian di BPM wilayah kerja Puskesmas Sukorame Kota Kediri. Berdasarkan tafsiran persalinan pada bulan Juni terdapat 27 ibu bersalin. Teknik sampling yang digunakan dalam penelitian ini adalah Consecutive Sampling dengan jumlah sampel 26 responden. Penelitian ini dilakukan mulai tanggal 9 Juni sampai dengan 12 Juli 2014. Tempat yang digunakan untuk penelitian adalah 6 BPM yang aktif melayani persalinan di Wilayah Kerja Puskesmas Sukorame Kota Kediri. Instrumen penelitian yang digunakan dalam penelitian ini adalah timbangan untuk mengukur berat badan dan lembar observasi untuk menilai produksi ASI. Analisa data bivariat dilakukan dengan menggunakan uji Fisher Exact Test.

\section{HASIL PENELITIAN}

Dibawah ini diuraikan hasil dari penelitian mengenai Pengaruh Pemberian Teknik Marmet Terhadap Produksi ASI pada Ibu Post Partum di BPM Wilayah Kerja Puskesmas Sukorame Kota Kediri. 
Tabel 1.1 Karakteristik Ibu Post Partum Berdasarkan Umur di BPM Wilayah Kerja Puskemas Sukorame Kota Kediri

\begin{tabular}{cccc}
\hline No. & $\begin{array}{c}\text { Usia } \\
\text { (Tahun) }\end{array}$ & Frekuensi & $\begin{array}{c}\text { Persentase } \\
(\%)\end{array}$ \\
1 & $<20$ & 2 & $7,69 \%$ \\
2 & $20-35$ & 17 & $65,38 \%$ \\
3 & $>35$ & 7 & $26,92 \%$ \\
& Jumlah & 26 & $100 \%$ \\
\hline
\end{tabular}

Berdasarkan tabel diatas, dapat diketahui bahwa karakteristik responden berdasarkan umur terbanyak berusia 20-35 tahun yaitu sebanyak 17 responden $(65,38 \%)$.

Tabel 1.2 Karakteristik Ibu Post Partum Berdasarkan Pendidikan di BPM Wilayah Kerja Puskesmas Sukorame Kota Kediri

\begin{tabular}{cccc}
\hline No. & Pendidikan & Frekuensi & $\begin{array}{c}\text { Persentase } \\
(\%)\end{array}$ \\
1 & Tidak & 1 & $3,84 \%$ \\
& sekolah & & \\
2 & SD & 4 & $15,38 \%$ \\
3 & SMP & 8 & $30,76 \%$ \\
4 & SMA & 8 & $30,76 \%$ \\
5 & Akademi & 0 & $0 \%$ \\
6 & Perguruan & 5 & $19,23 \%$ \\
& Tinggi & & \\
& Jumlah & 26 & $100 \%$ \\
\hline
\end{tabular}

Berdasarkan tabel diatas, dapat dilihat bahwa karakteristik responden berdasarkan pendidikan terbanyak responden berpendidikan SMA sebanyak 8 orang responden $(30,76 \%)$ dan SMP sebanyak 8 orang responden $(30,76 \%)$.

Tabel 1.3 Karakteristik Ibu Post partum Berdasarkan Pekerjaan di BPM Wilayah Kerja Puskesmas Sukorame Kota Kediri

\begin{tabular}{cccc}
\hline No. & Pekerjaan & Frekuensi & $\begin{array}{c}\text { Persentase } \\
(\%)\end{array}$ \\
1 & Ibu rumah & 14 & $53,84 \%$ \\
& tangga & & \\
2 & Swasta & 5 & $19,23 \%$ \\
3 & Wiraswasta & 2 & $0,07 \%$ \\
4 & PNS & 5 & $19,23 \%$ \\
& Jumlah & 26 & $100 \%$ \\
\hline
\end{tabular}

Berdasarkan tabel diatas, dapat disimpulkan bahwa karakteristik responden berdasarkan pendidikan terbanyak responden bekerja sebagai ibu rumah tangga yaitu sebanyak 14 orang responden $(53,84 \%)$.

\section{Tabel 1.4 Karakteristik Produksi ASI} Pada Ibu Post Partum Yang Tidak Diberikan Teknik Marmet di BPM Wilayah Kerja Puskesmas Sukorame Kota Kediri

\begin{tabular}{|c|c|c|c|}
\hline No. & $\begin{array}{l}\text { Produksi } \\
\text { ASI pada } \\
\text { hari ke-7 }\end{array}$ & Frekuensi & $\begin{array}{c}\text { Persentase } \\
(\%)\end{array}$ \\
\hline 1 & $\begin{array}{l}\text { Produksi } \\
\text { ASI } \\
\text { cukup }\end{array}$ & 7 & $53,84 \%$ \\
\hline 2 & $\begin{array}{c}\text { Produksi } \\
\text { ASI tidak } \\
\text { cukup }\end{array}$ & 6 & $46,15 \%$ \\
\hline & Jumlah & 13 & $100 \%$ \\
\hline
\end{tabular}

Berdasarkan tabel diatas, dapat diketahui bahwa produksi ASI pada ibu post partum kelompok yang tidak diberikan teknik marmet di BPM Wilayah Kerja Puskesmas Sukorame Kota Kediri sebanyak 7 orang responden produksi ASInya cukup $(53,84 \%)$.

Tabel 1.5 Karakteristik Produksi ASI Pada Ibu Post Partum Yang Diberikan Teknik Marmet di BPM Wilayah Kerja Puskesmas Sukorame Kota Kediri

\begin{tabular}{cccc}
\hline No & Produksi ASI & Frekuen & Persenta \\
pada hari ke-7 & si & se $(\%)$ \\
1 & $\begin{array}{c}\text { Produksi ASI } \\
\text { cukup }\end{array}$ & 13 & $100 \%$ \\
2 & $\begin{array}{c}\text { Produksi ASI } \\
\text { tidak cukup } \\
\text { Jumlah }\end{array}$ & 0 & $0 \%$ \\
& 13 & $100 \%$ \\
\hline
\end{tabular}

Berdasarkan data dari tabel di atas, dapat dijelaskan bahwa sebanyak 13 orang responden atau seluruh responden pada kelompok perlakuan produksi ASInya cukup (100\%). 


\section{Tabel 1.6 Tabel Silang Pengaruh Pemberian Teknik Marmet Terhadap Produksi ASI Pada Ibu Post Partum di BPM Wilayah Kerja Puskesmas Sukorame Kota Kediri}

\begin{tabular}{|c|c|c|c|c|}
\hline \multirow[t]{4}{*}{ No. } & \multirow[t]{4}{*}{ Kelompok } & \multicolumn{2}{|c|}{ Produksi ASI } & Jumlah \\
\hline & & ASI & ASI & \\
\hline & & Cukup & Tidak & \\
\hline & & & Cukup & \\
\hline 1 & $\begin{array}{c}\text { Diberikan } \\
\text { teknik } \\
\text { marmet }\end{array}$ & 13 & 0 & 13 \\
\hline 2 & $\begin{array}{c}\text { Tidak } \\
\text { diberikan } \\
\text { teknik } \\
\text { marmet }\end{array}$ & 7 & 6 & 13 \\
\hline & Jumlah & 20 & 6 & 26 \\
\hline
\end{tabular}

Berdasarkan tabel 4.6 dari 26 orang responden ibu post partum di BPM Wilayah Kerja Puskemas Sukorame Kota Kediri diketahui bahwa seluruh responden (13 orang responden) yang diberi teknik marmet produksi ASInya cukup, sedangkan responden yang tidak diberi teknik marmet, sebanyak 7 orang responden produksi ASInya cukup dan 6 orang responden produksi ASInya tidak cukup.

Hasil uji Fisher Exact test didapatkan hasil $\mathrm{p}$ hitung $=0,0074<\propto=0,05$ sehingga $\mathrm{H}_{\mathrm{o}}$ ditolak dan $\mathrm{H}_{1}$ diterima yang artinya ada pengaruh pemberian teknik marmet terhadap produksi ASI pada ibu post partum di BPM wilayah kerja Puskesmas Sukorame Kota Kediri

\section{PEMBAHASAN}

\section{Produksi ASI Pada Ibu Post Partum} Yang Tidak Diberi Teknik Marmet di BPM Wilayah Kerja Puskesmas Sukorame Kota Kediri

Berdasarkan hasil penelitian pada ibu post partum yang tidak diberikan teknik marmet di BPM wilayah kerja Puskesmas Sukorame Kota Kediri, didapatkan hasil bahwa sebanyak 7 responden mendapatkan produksi ASI cukup, sedangkan 6 responden didapatkan produksi ASI yang tidak cukup, dengan kriteria 4 responden mendapatkan hasil penurunan berat badan bayi melebihi $10 \%$ dari berat badan saat lahir dan 2 responden mendapatkan frekuensi buang air kecil kurang dari 6 kali dalam sehari. Sedangkan dari 7 responden yang mendapatkan produksi ASI cukup, 4 responden mendapatkan berat badan bayi yang meningkat dari berat badan saat lahir, 1 responden mendapatkan berat badan yang tetap dari berat badan saat lahir, dan 2 responden mengalami peunurunan berat badan bayi tetapi tidak melebihi $10 \%$ dari berat badan bayi saat lahir.

Terdapatnya 7 responden kelompok kontrol yang mendapatkan produksi ASI cukup dapat disebabkan salah satunya karena faktor usia ibu. Berdasarkan hasil penelitian sebagian besar responden (6 responden) pada kelompok kontrol yang mendapatkan produksi ASI cukup berada dalam rentang umur 20-35 tahun. Umur ibu berpengaruh terhadap produksi ASI. Ibu yang umurnya muda lebih banyak memproduksi ASI dibandingkan dengan ibu yang sudah tua (Soetjiningsih, 2005). Menurut Biancuzzo (2003) bahwa ibu-ibu yang lebih muda atau umurnya kurang dari 35 tahun lebih banyak memproduksi ASI dari pada ibu-ibu yang lebih tua.

Fenomena adanya hambatan dalam pengeluaran ASI pada awal menyusui menjadi kendala dalam pemberian ASI secara dini. Salah satu penyebab produksi ASI kurang adalah masih kurangnya asupan nutrisi untuk mendukung proses menyusui (Soetjiningsih, 2005). Proses produksi ASI membutuhkan asupan nutrisi yang cukup dari ibu menyusui sehingga proses produksi ASI dapat berjalan dengan lancar (Roesli, 2008). Hasil penelitian yang dilakukan Rahayu (2012) yang berjudul faktor - faktor yang mempengaruhi produksi ASI pada ibu nifas diperoleh hasil faktor makanan mempunyai pengaruh signifikan terhadap produksi ASI $(\rho=0,018)$. 
Hasil penelitian ini menunjukkan bahwa sebanyak 26 ibu post partum mengatakan tidak tarak makanan sehingga konsumsi makanan pada responden harusnya tercukupi dan kebutuhan nutrisi pada ibu dapat terpenuhi serta tidak menjadi penghalang pada kecukupan produksi ASI Ibu post partum. Masih adanya 6 responden pada kelompok kontrol dengan produksi ASI tidak cukup diperlukan lebih dalam lagi untuk pemantauan konsumsi makanan selama di rumah. Makanan merupakan bahan yang penting untuk proses produksi ASI. Makanan yang kurang memenuhi jumlah kebutuhan ibu per hari menyebabkan produksi ASI tidak cukup. Karena dalam proses produksi ASI diperlukan kandungan gizi makanan untuk mendapatkan jumlah ASI yang dibutuhkan oleh bayi.

Selain faktor yang mempengaruhi produksi ASI seperti makanan dan gizi ibu saat menyusui, produksi ASI juga dipengaruhi oleh faktor psikis. Kondisi jiwa ibu yang selalu dalam keadaan tertekan, sedih, kurang percaya diri dan berbagai bentuk ketegangan emosional akan menurunkan volume ASI bahkan tidak akan terjadi produksi ASI. Oleh karena itu untuk memproduksi ASI yang baik, ibu harus dalam keadaan tenang (Kristiyansari, 2009).

Berdasarkan teori faktor psikologis ibu merupakan faktor yang penting dimana dukungan dari orang terdekat dan lingkungan, sangat mempengaruhi kesiapan psikologis ibu untuk menyusui. Kondisi jiwa ibu yang tenang dan tidak cemas dapat membantu meningkatkan kepercayaan diri sehingga ibu dapat menyusui dengan baik.

\section{Produksi ASI Pada Ibu Post Partum Yang Diberi Teknik Marmet di BPM Wilayah Kerja Puskesmas Sukorame Kota Kediri}

Berdasarkan hasil penelitian yang dilakukan pada tanggal 9 Juni -12 Juli 2014 terhadap ibu post partum yang diberikan teknik marmet di BPM wilayah kerja Puskesmas Sukorame Kota Kediri, didapatkan hasil bahwa seluruh responden (100\%), yaitu sebanyak 13 orang responden yang diberi teknik marmet mendapatkan produksi ASI yang cukup.

Berdasarkan hasil observasi produksi ASI dilihat dari indikator berat badan bayi, sebagian besar responden (8 orang responden) didapatkan hasil berat badan bayi yang meningkat dari berat badan saat lahir, 2 responden mendapatkan berat badan yang tetap dari berat badan saat lahir, dan 3 orang responden mendapatkan berat badan bayi yang menurun tetapi tidak melebihi $10 \%$ dari berat badan bayi saat lahir. Sedangkan berdasarkan frekuensi buang air kecil, didapatkan seluruh responden frekuensi buang air kecilnya 6-8 kali dalam sehari. Pencapaian dari produksi ASI yang cukup dari seluruh responden ini kemungkinan dapat dipengaruhi oleh pemberian teknik marmet yang dilakukan oleh peneliti kepada responden 2 kali dalam sehari selama 7 hari.

Menurut Dalzell (2010) dengan melakukan teknik marmet dapat membantu kunci reflek pengeluaran ASI (letdown reflex) yang efektif dalam harihari pertama menyusui, karena tebalnya konsistensi kolostrum dan ketika susu matang diproduksi. Teknik Marmet mengembangkan metode pijat dan stimulasi untuk membantu kunci reflek pengeluaran ASI. Keberhasilan dari teknik ini adalah kombinasi dari metode pijat dan pengeluaran ASI yang membantu refleks pengeluaran susu (Milk Ejection Reflex) sehingga ibu menyusui yang sebelumnya hanya mampu mengeluarkan ASI sedikit atau tidak sama sekali, mendapatkan hasil yang sangat baik dengan teknik ini (Hormann, 2006).

Hasil penelitian ini menunjukkan bahwa pemberian teknik marmet mempengaruhi produksi ASI ibu post partum yang dapat dicapai oleh seluruh responden perlakuan. Pada sebagian ibu post partum dapat terjadi hambatan 
pengeluaran ASI pada hari pertama setelah persalinan sehingga terjadi perubahan perilaku dalam masyarakat khususnya ibu-ibu yang cenderung menolak menyusui bayinya sendiri dan lebih memilih menggunakan susu formula dengan alasan produksi ASInya hanya sedikit atau tidak keluar sama sekali. Keadaan ini tentu memberikan dampak negatif terhadap status kesehatan, gizi serta tingkat kecerdasan anak. Oleh karena itu, untuk menanggulangi permasalahan tersebut perlu dilakukan upaya preventif dan promotif dalam meningkatkan penggunaan ASI.

Pembentukan air susu sangat dipengaruhi oleh hormon prolaktin dan kontrol laktasi serta penekanan fungsi laktasi. Pada seorang ibu yang menyusui dikenal 2 refleks yang masing-masing berperan sebagai pembentukan dan pengeluaran air susu refleks prolaktin dan refleks "Let down" (Proverawati, 2010). Produksi ASI yang rendah bisa diakibatkan dari kurang sering menyusui atau memerah payudara dan memijat payudara. Teknik marmet merupakan kombinasi antara cara memerah ASI dan memijat payudara sehingga reflek keluarnya ASI dapat optimal. Pengosongan ASI dari sinus laktiferus yang terletak di bawah areola diharapkan akan merangsang pengeluaran hormon prolaktin yang merangsang mammary alveoli untuk memproduksi ASI. Makin banyak ASI dikeluarkan atau dikosongkan dari payudara maka akan semakin banyak ASI akan diproduksi (Astutik, 2014).

Mardiyaningsih (2010) dalam penelitiannya menjelaskan bahwa kombinasi teknik marmet dan pijat oksitosin efektif dalam meningkatkan produksi ASI ibu post seksio sesarea, dimana ibu post seksio sesarea yang mendapatkan intervensi kombinasi teknik marmet dan pijat oksitosin berpeluang 11,5 kali lebih besar produksi ASI nya lancar dibandingkan dengan kelompok kontrol.
Bowles (2011) menyatakan bahwa untuk produksi ASI dan kelancaran pengeluaran ASI memerlukan rangsangan pada otot-otot payudara agar kelenjar payudara bekerja dengan lebih efektif, sehingga otot-otot akan berkontraksi lebih baik dan kontraksi yang baik ini diperlukan dalam proses laktasi. Rangsangan pada otot-otot payudara ini dapat dilakukan dengan pemijatan atau masase payudara salah satunya melalui pemberian teknik marmet ini.

Berdasarkan penelitian ini didapatkan bahwa seluruh responden mendapatkan produksi ASI yang cukup. Hal ini dapat disebabkan salah satunya melalui diberikannya rangsangan pada otot-otot payudara agar bekerja lebih efektif melalui pemberian teknik marmet yang dapat merangsang refleks pengaliran / let down refleks yang memicu keluarnya ASI. Sehingga dengan dilakukannya teknik marmet pada ibu post partum dapat membantu meningkatkan kecukupan produksi ASI pada ibu post partum.

\section{Pengaruh Pemberian Teknik Marmet Terhadap Produksi ASI Pada Ibu Post Partum di BPM Wilayah Kerja Puskesmas Sukorame Kota Kediri}

Berdasarkan hasil analisa uji Fisher Exact Test didapatkan hasil $p$ hitung $=$ $0,0074<\propto=0,05$ sehingga $\mathrm{H}_{0}$ ditolak dan $\mathrm{H}_{1}$ diterima yang artinya ada pengaruh pemberian teknik marmet terhadap produksi ASI pada ibu post partum di BPM wilayah kerja Puskesmas Sukorame Kota Kediri.

Hasil penelitian ini menunjukkan bahwa proporsi ibu dengan produksi ASI cukup ditemukan paling banyak pada kelompok umur 20-35 tahun dengan responden sebanyak 15 orang $(75 \%)$ dari seluruh responden (20 orang) yang mendapatkan produksi ASI cukup. Umur merupakan salah satu faktor yang dapat mempengaruhi produksi ASI, ibu yang usianya lebih muda akan lebih banyak memproduksi ASI dibandingkan dengan 
ibu yang usianya lebih tua (Biancuzzo, 2003). Pendapat lain oleh Pudjiati (2005) bahwa ibu yang berumur 19-25 pada umunya dapat menghasilkan cukup ASI dibandingkan dengan ibu yang berumur 30 tahun ke atas.

Penelitian yang dilakukan oleh Moore dan Coty (2006) menunjukkan bahwa keberhasilan menyusui tidak ditentukan dari tingkat pendidikan ibu akan tetapi oleh informasi tentang menyusui yang diterima ibu pada saat prenatal. Ibu post partum ternyata membutuhkan pendidikan tentang menyusui pada saat prenatal dan informasi yang diberikan harus konsisten dan realistis. Hasil penelitian ini juga menujukkan bahwa ibu yang produksi ASInya cukup sebagian besar berpendidikan rendah. Sebanyak 11 orang responden $(55 \%)$ yang mendapatkan produksi ASI cukup memiliki pendidikan yang rendah.

Tingkat pendidikan seseorang tidak dapat dijadikan pedoman bahwa seseorang akan berhasil pada saat proses menyusui. Akan tetapi informasi yang benar dan diterima tentang proses menyusui sebelumnya akan menentukan keberhasilan proses menyusui. Seseorang yang mempunyai pendidikan rendah akan tetapi dia memperoleh informasi yang benar tentang menyusui maka dia akan berhasil dalam proses menyusui. Pengetahuan yang memadai akan meningkatkan rasa percaya diri ibu pada saat menyusui. Rasa percaya diri inilah yang akan memperlancar produksi ASI pada masa laktasi, sehingga pendidikan kesehatan tentang menyusui yang diberikan kepada ibu pada saat masa kehamilan dapat membantu ibu untuk mempunyai keyakinan bahwa dia akan berhasil dalam proses menyusui.

Terjadinya penyulit pada saat dilakukan proses laktasi tentunya akan sangat merugikan ibu maupun bayi. Fenomena yang ditemukan di lapangan bahwa produksi ASI menurun pada awal meyusui. Pada umumnya masalah tidak keluar atau terhambatnya produksi ASI dikarenakan dua hal yaitu ASI yang penuh dan saluran ASI yang tersumbat. ASI yang tidak langsung keluar setelah melahirkan adalah hal yang wajar, karena itu ibu post partum harus memancing keluarnya ASI salah satunya melalui teknik marmet. Teknik marmet merangsang reflek keluarnya ASI (let down reflex) yang merangsang reflek pengaliran produksi ASI.

Hasil penelitian ini sudah sesuai dengan teori, didukung pula dengan adanya hasil penelitian Setiawandari (2013) yang membuktikan bahwa teknik marmet berpengaruh dalam meningkatkan produksi ASI ibu post partum. Jika teknik marmet ini diterapkan oleh ibu post partum maka masalah menyusui yang muncul pada hari-hari pertama kelahiran seperti ASI tidak lancar, ASI belum keluar yang menyebabkan ibu memutuskan untuk memberikan susu formula kepada bayinya dapat diatasi sehingga dapat meningkatkan angka cakupan pemberian ASI pada satu jam pertama kelahiran bahkan pemberian ASI eksklusif.

\section{SIMPULAN DAN SARAN}

Berdasarkan hasil penelitian pengaruh pemberian teknik marmet terhadap produksi ASI pada ibu post partum di BPM Wilayah Kerja Puskesmas Sukorame Kota Kediri yang dilakukan pada tanggal 9 Juni sampai 12 Juli 2014 maka dapat disimpulkan sebagai berikut :

1. Seluruh responden yang diberi teknik marmet mendapatkan produksi ASI yang cukup pada hari ke-7.

2. Sebagian besar responden yang tidak diberi teknik marmet mendapatkan produksi ASI yang cukup pada hari ke-7.

3. Ada pengaruh pemberian teknik marmet terhadap produksi ASI pada ibu post partum di BPM Wilayah Kerja Puskesmas Sukorame Kota Kediri.

Berdasarkan hasil penelitian dan kesimpulan yang telah dirumuskam di atas 
maka perlu disampaikan saran sebagai berikut :

1. Bagi Tempat Penelitian

Dengan adanya hasil penelitian ini diharapkan dapat digunakan sebagai peningkatan mutu pelayanan ibu post partum dengan memperhatikan produksi ASI yang dapat berdampak pada proses pemberian ASI, misal dengan mengadakan sosialisasi teknik marmet pada ibu saat ANC / masa kehamilan.

2. Bagi Institusi Pendidikan

Dengan adanya hasil penelitian ini diharapkan dapat digunakan untuk menambah wawasan dan informasi serta data dasar untuk penelitian selanjutnya.

3. Bagi peneliti selanjutnya

Bagi peneliti selanjutnya, diharapkan dapat dilakukan penelitian lanjutan dengan membandingkan antara intervensi teknik marmet dan breast care, menyusui dini dan teratur untuk meningkatkan produksi ASI pada ibu post partum.

\section{DAFTAR PUSTAKA}

Anggraini, Y. 2010. Asuhan Kebidanan Masa Nifas. Yogyakarta: Pustaka Rihama.

Astutik, R. 2014. Payudara dan Laktasi. Jakarta: Salemba Medika.

Biancuzzo, M. 2003. Breastfeeding the newborn: Clinical strategies for nurses. St. Louis: Mosby.

Bowles, B.C., 2011. Breast Massage A "Handy" Multipurpose Tool to Promote Breastfeeding Succes. United States: Lactation Consultan Association.

http://www.clinicallactation.org/site s/default/files/articlepdf/CL24bowles.pdf. Diakses pada tanggal 13 Februari 2014.

Dalzell, J. 2010. Breastfeeding. United Kingdom: Radcliffe Publishing Ltd.
Depkes gizi. 2013. PEKAN ASI SEDUNIA 2013.

http://www.gizikia.depkes.go.id/arc hives/8659. Diakses pada tanggal 3 Februari 2014.

Derni, M. 2007. Serba-serbi Menyusui. Depok: WaRM Publishing

Dewi, V. 2012. Asuhan Kebidanan pada Ibu Nifas. Jakarta: Salemba Medika.

Gibney, M.J. 2008. Gizi kesehatan Masyarakat. Terjemahan oleh Andry Hartono,dkk. Jakarta: EGC.

Hidayat, AAA. 2007. Metode Penelitian Keperawatan dan Teknik Analisis Data. Jakarta: Salemba Medika.

Hormann, E. 2006. Breastfeeding an Adopted Baby and Relactation. United States of America: La Leche League International.

Kristiyansari, W. 2009. ASI, Menyusui \& Sadari. Yogyakarta: Muha Medika.

La Leche League International. 27 Oktober 2003. Manual Expression of Breast Milk Marmet Technique. http://lllrochester.weebly.com/uploa ds/7/9/5/4/795404/marmet_techniqu e_tearoff.pdf. Diakses pada tanggal 13 Februari 2014.

Mardiyaningsih, E. 2010. Efektifitas kombinasi teknik marmet dan pijat oksitosin terhadap Produksi asi ibu post seksio di rumah sakit wilayah jawa tengah. Depok: FIK UI. http://lontar.ui.ac.id/file?file=digital/ 20282666-

T+Eko+Mardiyaningisih.pdf.

Diakses pada tanggal 13 Februari 2014.

Maryunani, A. 2012. Inisiasi Menyusui Dini, ASI Eksklusif dan Manajemen Laktasi. Jakarta: Trans Info Medika.

Moore, E. R., Coty, M.B. 2006. Prenatal and postpartum focus groups with primiparas: breastfeeding attitudes, support, barriers, self-efficacy, and intention. Journal Pediatrics Health Care 20, 35-46. 
Notoatmodjo, S. 2010. Metodologi Penelitian Kesehatan. Jakarta: Rineka Cipta

Nugroho, T. 2011. ASI dan Tumor Payudara. Yogyakarta: Nuha Medika.

Nurdiansyah, N. 2011. Buku Pintar Ibu dan Bayi. Jakarta: Bukune.

Nursalam. 2011. Konsep dan Penerapan Metodologi Penelitian Ilmu Keperawatan Pedoman Skripsi, Tesis, dan Instrume Penelitian keperawatan. Jakarta: Salemba Medika.

Prasetyono, D. 2009. Buku Pintar ASI eksklusif pengenalan, praktik, dan pemanfaatannya. Jogjakarta: Diva Press.

Proverawati, A. 2010. Kapita Selekta ASI dan Menyusui. Yogyakarta: Nuha Medika.

Pudjiadi. 2005. Ilmu gizi klinis pada anak Edisi 4. Jakarta: FK UI.

Rahayu, D. 2012. Faktor - Faktor yang Mempengaruhi Produksi ASI pada Ibu

Nifas.http://stikesbaptis.ac.id/utama/ index.php?option=com_docman\&ta sk=doc_download\&gid=17\&Itemid =111. Diakses tanggal 18 Juli 2014.

Ramaiah, S. 2006. ASI dan Menyusui. Jakarta: Buana Ilmu Populer.

Saleha, S. 2009. Asuhan Kebidanan pada Masa Nifas. Jakarta: Salemba Medika.

Sears, W. 2007. The Baby Book, Everything You Need to Know About Your Baby From Birth to Age Two. Terjemahan oleh Dwi karyani, dkk. Jakarta: SERAMBI ILMU SEMESTA.

Setiawandari. 2013. Perbedaan Pengaruh Teknik Marmet Dengan Pijat Oksitosin Terhadap Produksi ASI Ibu Postpartum Di Rumah Sakit Ibu Dan Anak Ibi Surabaya. http://s2mkk.pasca.uns.ac.id/?m=20 1404\&paged $=5$. Diakses tanggal 18 Juli 2014.
Soetjiningsih. 2005. ASI, Petunjuk Untuk Tenaga Kesehatan. Jakarta : EGC

Sugiyono. 2012. Statistika Untuk Penelitian. Bandung: Alfabeta.

Suryawati, C. 2007. Faktor Sosial Budaya dalam Praktik Perawatan Kehamilan, Persalinan, dan Pasca Persalinan di Kecamatan Bangsri Kabupaten Jepara. http://ejournal.undip.ac.id/index.php /jpki/article/view/2800. Diakses tanggal 18 Juli 2014.

Unicef Indonesia. 2013. ASI adalah penyelamat hidup paling murah dan efektif di dunia. http://www.unicef.org/indonesia/id/ media_21270.html. Diakses pada tanggal 3 februari 2014.

Weiss, E. 2006. The better Way to Breastfeed. LCCE.CLC.

Widiani, R. 2013. Cakupan ASI 42 Persen, Ibu Menyusui Butuh Dukungan.

http://health.kompas.com/read/2013/ 12/21/0917496/Cakupan.ASI.42.Per sen.Ibu.Menyusui.Butuh.Dukungan. Diakses pada tanggal 3 Februari 2014.

Widuri, H. 2013. Cara Mengelola ASI Eksklusif Bagi Ibu Bekerja. Yogyakarta: Gosyen Publishing.

Wiji, R.N. 2013. ASI dan Panduan Ibu Menyusui. Yogyakarta: Nuha Medika 